\title{
Conceptual model to identify factors with influence in Brazilian beef consumption
}

\section{Fernanda Scharnberg Brandão1, Júlio Otávio Jardim Barcellos', Paulo Dabdab Waquil², Tamara Esteves de Oliveira ${ }^{3}$, Miguelangelo Gianezini ${ }^{4}$, Eduardo Antunes Dias ${ }^{1}$}

\author{
1 Universidade Federal do Rio Grande do Sul, Departamento de Zootecnia, Porto Alegre, RS, Brasil. \\ 2 Universidade Federal do Rio Grande do Sul, Departamento de Ciências Econômicas, Porto Alegre, RS, Brasil. \\ ${ }^{3}$ Universidade Federal do Rio Grande do Sul, Programa de Pós-graduação em Agronegócios, Porto Alegre, RS, Brasil. \\ ${ }^{4}$ Universidade do Extremo Sul Catarinense, Programa de Pós-graduação em Desenvolvimento Socioeconômico, Criciúma, SC, Brasil.
}

\begin{abstract}
The complexity of the consumers' behavior has taken the food industry to a new level of dynamism. Therefore, understanding the factors that influence this behavior is decisive for the differentiation of products to niche markets and even to adjust the supply according to consumers' expectancy. This article proposes a conceptual model to identify the factors influencing beef consumption in Brazil. The methodological approach was characterized by a systematic review through a synthesis of research related directly to this topic. Therefore, 76 papers published during the 2000-2014 period, including official documents (statistics), full research papers, abstracts, proceedings, and reports, were selected. Four main factors were related to influences in consumer behavior and/or directly in beef consumption: sociocultural, economic, health/food, and environmental. Among these dimensions, there was an emphasis on recent publications related to health/food and the environment. The compilation and analysis of these papers enabled the conception of the proposed model and suggests the consideration of four main dimensions in beef consumption.
\end{abstract}

Key Words: agribusiness, beef cattle, behavior, price, sustainability

\section{Introduction}

The choice to purchase a food is a complex behavior (Shepherd et al., 1991) influenced by different factors that play an important role in consumer's expectations and perceptions (Chiou et al., 2009). Some consumers become more cautious when searching for safety, high quality (Abreu et al., 2012), authenticity, health, and tradition in their food (Ilbery and Kneafsey, 2000). Therefore, in an attempt to meet this demand there is a need for in-depth knowledge of the consumer behavior (Kopetz et al., 2012).

The increased demand for food is a global trend for the next decades, highlighting the existing difficulty in food supply for the global population (FAO, 2010). Therefore, the food industry has assumed a unique situation, driven by unprecedented changes in economic, technological, and social structures. Given these changes, a new consumption pattern in the population should be acknowledged in order to point out the factors that influence this behavior.

Received October 30, 2014 and accepted April 7, 2015. Corresponding author: fernanda.fsbrandao@gmail.com http://dx.doi.org/10.1590/S1806-92902015000600003

Copyright $(2015$ Sociedade Brasileira de Zootecnia. This is an Open Access article distributed under the terms of the Creative Commons Attribution Non-Commercial License, which permits unrestricted non-commercial use, distribution, and reproduction in any medium, provided the original work is properly cited.
In Brazil, social and economic changes have also influenced the consumer behavior. The increase in the population income, particularly that of classes $\mathrm{C}$ and $\mathrm{D}$ (IBGE, 2012), has changed the food purchasing habits, allowing for the inclusion of food preferences, which, for financial reasons, once could not be considered priorities, such as beef (Pindyck and Rubinfeld, 2004).

Beef is one of the most important items of the Brazilian diet, and the domestic market is responsible for the consumption of more than $70 \%$ of the national production (IBGE, 2012). Despite its importance, research aimed at understanding the particularities and determining the population's consumption pattern is still incipient.

Conceptual models are commonly applied to represent the peculiarities of each context and to assist the understanding of existing concepts in different areas. Some studies indicate this research approach in several areas: automobiles and cellulose (Fuchs et al., 2009), quantum mechanics (Greca et al., 2001), information technology science (Inazawa and Baptista, 2012), and food (Pinho et al., 2012). However, each template encompasses characteristics inherent to each activity, adapted by region and by type of product. One of the conceptual models proposed for food (Pinho et al., 2012) focused only on the socioeconomic and demographic factors of the population. 
However, the conceptual models proposed for food disregard the beef producing particularities and the effect of these properties on the food choices. With respect to this consumer behavior, in addition to the economic and socio-cultural factors, other important issues emerge such as sustainability, environmental impact, scarcity of water resources (Bowman et al., 2012; Ridoutt et al., 2012; Ruviaro et al., 2012), intensification of the production systems, animal welfare (Chandler et al., 2011) and obesity (FAO, 2010), as well as changes in the lifestyle of Brazilians (IBGE, 2012).

Therefore, this article proposes a conceptual model adapted to the Brazilian reality able to identify the factors that influence beef consumption aiming to develop a deeper understanding of this issue.

\section{Material and Methods}

The methodological procedure adopted consisted of a systematic review through a research synthesis related to trends and influential factors in beef consumption. This review was based on articles available in the Scielo and Web of Science databases. In addition, we analyzed documents and statistical reports published in governmental and nongovernmental organizations.

The documents met the criterion of simultaneous combination of keywords used for searching "food", "consumption", "beef", "trends", "influence factors", "behavior", and "consumer" in Portuguese, English, and Spanish. After a systematic reading of these documents, 76 documents that met the search criteria, published between the years 2000-2014, were selected to cover the most recent discussions related to the topic. Through a questionnaire, 32 experts ranked the selected variables that affect consumption. Thus, the data were organized and synthesized in a framework that highlights the influential factors for beef consumption, their reference, and the corresponding dimension.

After the first phase, the proposed conceptual model with the influential factors identified in the systematic review was again subjected to the opinion of the same group of experts from Brazil's beef chain supply. These experts belonged to the segments of production (6), industry (2), retail (2), institutional bodies (10), and education/research institutions (12). The specialists were selected in accordance with the inclusion criteria predefined for leveling the sample into the subjected and included working in the beef production chain with at least five years' experience and high education (university degree). The sample of experts demonstrated, on average, 45 years of age (minimum and maximum of 28 and 70 years, respectively). The revision of the model by specialists took place on the Internet from April to June, 2014.

\section{Results}

The systematic review highlighted four main dimensions that influence beef consumption, composed of the following factors: sociocultural, economic, health/ food, and environmental (Table 1). Thus, we propose a model to adapt to the Brazilian context with the main dimensions and influential factors on beef consumption (Figure 1).

\section{Discussion}

The results indicate that several factors can influence the consumers' behavior and characteristics of food consumption, as stated by Kotler (2006). Among these factors,some particular issues stand out, such as the legislation and environmental impact. The studies devoted to this topic struggled to include all factors of influence in consumption, since these components can vary according to the product, quantity, or site of purchase (Kotler, 2006).

Although the factors related to sociocultural and economic dimensions are commonly cited in the classic (Kotler, 2006) and recent publications (IBGE, 2012; Mitchell et al., 2012; Olsen et al., 2012; Rezende and

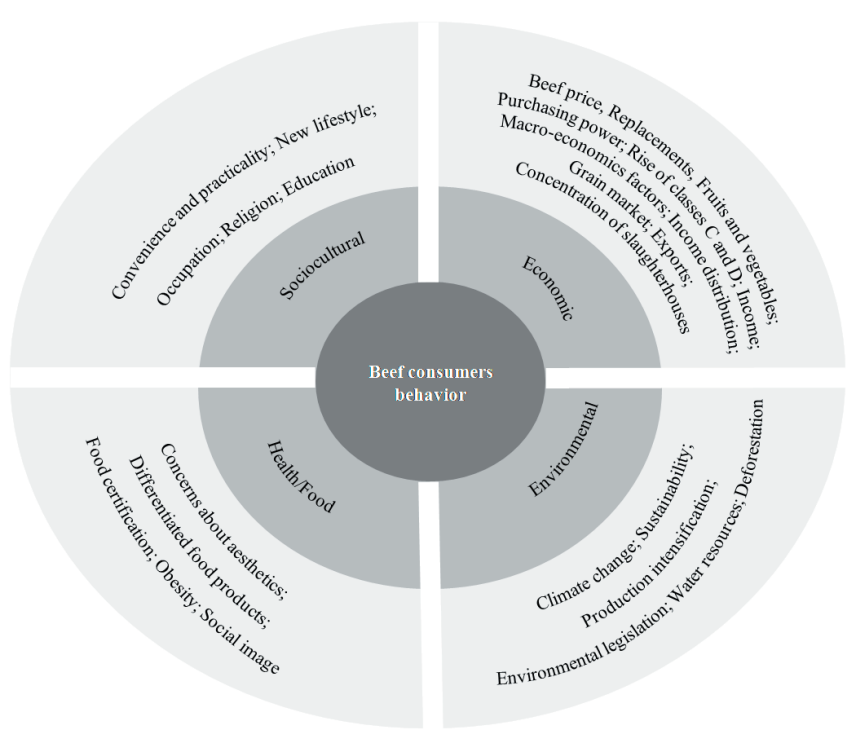

Figure 1 - Main dimensions and their influence factors in beef consumption in Brazil. 
Table 1 - Main drivers for beef consumption in Brazil organized by dimension of influence: sociocultural, economic, health/food, and environmental

\begin{tabular}{|c|c|c|}
\hline Influential factors in beef consumption & References & Dimension \\
\hline Convenience, use of time and practicality & Rezende and Avelar (2012); Mitchell et al. (2012); Olsen et al. (2012). & \multirow{3}{*}{ Sociocultura } \\
\hline $\begin{array}{l}\text { New lifestyle (urbanization; women and young people in } \\
\text { the labor market) }\end{array}$ & FAO (2010); IBGE (2012). & \\
\hline $\begin{array}{l}\text { Demographic characteristics (increased lifespan, reduced } \\
\text { number of children per family, occupation, religion, } \\
\text { education, culture) }\end{array}$ & $\begin{array}{l}\text { Godfray et al. (2010); Kotler (2006), Medeiros and Cruz (2006); } \\
\text { Soler and Plaza (2012); Taylor et al. (2012); Realini et al. (2013); } \\
\text { Insch and Jackson (2014). }\end{array}$ & \\
\hline Food prices (beef; replacements) & IBGE (2012); FAO (2010); Kotler (2006). & \multirow{4}{*}{ Economic } \\
\hline Revenues & World Bank (2012); OECD (2012); Tellez-Delgado et al. (2012). & \\
\hline Unfavorable macro-economic factors & United Nations (2012); IMF (2012). & \\
\hline $\begin{array}{l}\text { Brazilian beef exportations (concentration of } \\
\text { slaughterhouses) }\end{array}$ & IBGE (2012); FAO (2010). & \\
\hline $\begin{array}{l}\text { Differentiated food (functional foods, portioning, frozen, } \\
\text { organic) }\end{array}$ & Chander et al. (2011); Moser and Raffaelli (2012); Bonannoxs (2012) & \multirow[t]{2}{*}{$\begin{array}{l}\text { Health/ } \\
\text { Food }\end{array}$} \\
\hline Food certification & $\begin{array}{l}\text { Aprile et al. (2012); Brandão et al. (2012); Velho et al. (2009); } \\
\text { Barcellos et al. (2012). }\end{array}$ & \\
\hline $\begin{array}{l}\text { Climate change; sustainability (product life cycle analysis); } \\
\text { water resources }\end{array}$ & $\begin{array}{l}\text { Moser and Raffaelli (2012); Ruviaro et al. (2012); Notarniloca et al. (2012); } \\
\text { Stilmant et al. (2010); Behera et al. (2012); Vanhonacker et al. (2013); } \\
\text { Grimshaw et al. (2014). }\end{array}$ & \multirow[t]{3}{*}{ Environment } \\
\hline Intensification of production in Brazil; deforestation & Bryant et al. (2011); Stilmant et al. (2010); White et al. (2010). & \\
\hline Environmental legislation & $\begin{array}{l}\text { Hildebrandt and Islam (2012); Voordouw et al. (2012); } \\
\text { Poccard-Chapuis et al. (2010). }\end{array}$ & \\
\hline
\end{tabular}

Avelar, 2012; Tellez-Delgado et al., 2012), their results highlight the environment and health/food dimensions related to beef consumption, which was not found in this study.

The growing concern regarding the risks inherent to food, usually related to the misuse of chemicals in agriculture, promoted the search for alternative production methods (Aprile et al., 2012). It is noted that beef consumers are concerned and willing to pay more for safer products such as those traced (Barcellos et al., 2012), certified (Elder et al., 2009), or with origin identification (Insch and Jackson, 2014; Realini et al., 2013).

Environmental issues also stand out in consumers' desires (Grimshaw et al., 2014; Vanhonacker et al., 2013). Recently, Brazil has been ranked among the first positions (in 17 countries analyzed) about the environmentally friendly behavior among consumers (Barcellos et al., 2011). In general, this awareness demands more than quality attributes (e.g., low price, sanitary-hygienic quality, flavor, etc.), like products without chemical residues, with true concerns regarding animal welfare (Chandler et al., 2011), and with no harm for the environment.
A significant part of beef consumers have access to the results of surveys, research studies, and methods capable of measuring, for example, the environmental impact through the emission of greenhouse gases and deforestation caused by the food production (Bowman et al., 2012; Ruviaro et al., 2012), or even the use of water in the production systems (Ridoutt et al., 2012). That information shapes consumers' awareness and may affect their consumption decisions, particularly for products purchased frequently.

Of the total publications analyzed, most papers are recent, especially within the health/food and environmental dimensions (Table 1). Particularly for beef consumption, a range of factors associated with food safety and environmental impact have driven publications, indicating possible influences in the consumption of this product.

The proposed conceptual model is a diagram indicating the factors that can influence beef consumption. Such model, adapted to Brazilian beef consumption, presents its dimensions of influence with a varied range of elements classified into the following dimensions: sociocultural (six factors), economic (11 factors), health/food (six factors), and environmental (five factors). The possibility 
of interaction among dimensions and among the factors of each dimension was considered.

It is obvious that the consumers' behavior is influenced by endogenous (such as preference for differentiated products) and exogenous (such as macro-economic) factors (Kopetz et al., 2012). This model considered both categories within each dimension. In general, it is possible that in a certain period of time one dimension has greater influence over another regarding beef consumption, while in another scenario this relationship is reversed. For instance, in 2013 the economic dimension had greater influence on Brazilian beef consumption, while in Europe, at the same time, the environmental dimension presented greater importance than other dimensions.

Regarding the population, the income levels and the purchase power are decisive in targeting the priority factors in consumption (IBGE, 2012), because there is a direct relationship between the increase in revenues and beef consumption in developing countries, particularly for the low-income population (World Bank, 2012).

Although the previous conceptual models for food consumption disregarded beef in their analyses, this proposal comprehends the main characteristics of Brazilian cattle production and its consumers. Moreover, especial effort has been made in adding the new challenges for the future of food production, such as sustainability and the ethical relationship with natural resources and animal welfare. The authors believe it is vital to consider those principles when researching food consumers.

This model also provides a way to identify factors that can determine beef consumption in Brazil because it identifies the dimensions and the factors that guide the consumption in Brazil. From the application of this model, it is possible to identify, for instance, if the sustainability and environmental issues, considered important by some European consumers of pork (Barcellos et al., 2011), are more influential than the price for beef consumption in Brazil.

It is important to note that the proposed conceptual model, even being verified by experts of the beef production chain, was based on a systematic review of the literature. Moreover, those aspects should be considered in future research, which could be adapted to other countries or even other products, indicated for both quantitative and qualitative empirical studies.

The main difficulty observed in this study is the attempt to reflect statically the consumption-behavior dynamism and the constant changes in consumption patterns. Thus, a periodic update over the influential factors is necessary and recommended.

\section{Conclusions}

This conceptual model improves the understanding of the behavior of Brazilians regarding beef consumption because it summarizes the main drivers. The model can assist the structuring of beef consumer surveys and allows for better predictions in these studies because it reflects the Brazilian reality by listing four dimensions (economic, sociocultural, health/food, and environmental) composed of 28 influential factors for the beef consumption. It should be noted that this model could be adapted to other countries or even to other products. The economic dimension is preponderant for the purchase, but with the increase in consumer income, other dimensions such as healthy/ food and environmental are valued by the consumer. Nevertheless, depending on the context, it may require some adjustments in the influential factors, being indicated for both quantitative and qualitative empirical studies.

\section{Acknowledgments}

We gratefully acknowledge the financial support granted by CAPES (Coordenação de Aperfeiçoamento de Pessoal de Nível Superior).

\section{References}

Abreu, D. A. P.; Cruz, J. M. and Losada, P. P. 2012. Active and intelligent packaging for the food industry. Food Reviews International 28:146-187.

Aprile, M. C.; Caputo, V. and Nayga Junior, R. M. 2012. Consumers' valuation of food quality labels: the case of the European geographic indication and organic farming labels. International Journal of Consumer Studies 36:158-165.

Barcellos, J. O. J.; Abicht, A. M.; Brandão, F. S.; Canozzi, M. E. A. and Collares, F. C. 2012. Consumer perception of Brazilian traced beef. Revista Brasileira de Zootecnia 41:771-774.

Barcellos, M. D.; Krystallis, A.; Saab, M. E. M.; Kügler, J. O. and Grunert, K. G. 2011. Investigating the gap between citizens' sustainability attitudes and food purchasing behavior: empirical evidence from Brazilian pork consumers. International Journal of Consumer Studies 35:391-402.

Behera, U. K.; Panigrahi, P. and Sarangi, A. 2012. Multiple water use protocols in integrated farming system for enhancing productivity. Water Resources Management 26:2605-2623.

Bonannoxs, A. 2012. Some like it healthy: demand for functional and conventional yogurts in the Italian market. Agribusiness 28:67-85.

Bowman, M. S.; Soares-Filho, B. S.; Merry, F. D.; Nepstad, D. C.; Rodrigues, H. and Almeida, O. 2012. Persistence of cattle ranching in the Brazilian Amazon: a spatial analysis of the rationale for beef production. Land Use Policy 29:558-568.

Brandão, F. S.; Ceolin, A. C.; Canozzi, M. E. A.; Révillion, J. P. P. and Barcellos, J. O. J. 2012. Confiança e agregação de valor em carnes com indicação geográfica. Arquivo Brasileiro de Medicina Veterinária e Zootecnia 64:458-464. 
Bryant, J. R.; Snow, V. O.; Cichota, R. and Jolly, B. H. 2011. The effect of situational variability in climate and soil, choice of animal type and $\mathrm{N}$ fertilization level on nitrogen leaching from pastoral farming systems around Lake Taupo, New Zealand. Agricultural Systems 104:271-280.

Chandler, M.; Subrahmanyeswari, B.; Mukherjee, R. and Kumar, S. 2011. Organic livestock production: an emerging opportunity with new challenges for producers in tropical countries. Revue Scientifique et Technique-Office International des Epizooties 30:969-983.

Chiou, W. B.; Yeh, L. and Chang, M. 2009. Effects of health-related claims on the differential threshold of consumers' sweetness sensation. Journal of Sensory Studies 24:621-633.

Elder, S. D.; Zerriffi, H. and Le Billon, P. 2012. Effects of fair trade certification on social capital: The case of Rwandan coffee producers. World Development 40:2355-2367.

European Commission. 2012. Euroestat. Data. Available at: $<$ http://epp.eurostat.ec.europa.eu/portal/page/portal/eurostat/home/>. Accessed on: Feb. 10, 2012.

FAO - Food and Agriculture Organization of the United Nations. 2010. Site Institucional. Estatísticas, produção. Available at: $<$ http://www.fao.org $>$. Accessed on: May 11, 2010.

Fuchs, P. G.; Macedo-Soares, T. D. L. A. and Russo, G. 2009. Modelo conceitual para avaliação de práticas e estratégias climáticas: resultados de sua aplicação nos setores automotivo e de papel e celulose no Brasil. Revista de Administração Pública 43:837-874.

Godfray, C. H.; Beddington, J. R.; Crute, I. R.; Haddad, L.; Lawrence, D.; Muir, J. F.; Pretty J.; Robinson S.; Thomas S. M. and Toulmin C. 2010. Food security: the challenge of feeding 9 billion people. Science 327:812-818.

Greca, I. M.; Moreira, M. A. and Herscovitz, V. E. 2001. Uma proposta para o ensino de mecânica quântica. Revista Brasileira de Ensino de Física 23:444-457.

Grimshaw, K.; Miller, R. K.; Palma, M. A. and Kerth, C. R. 2014. Consumers perception of beef, pork, lamb, chicken and fish. Meat Science 96:443.

Hildebrandt, G. and Islam, R. 2012. Rights food imitations replace consumer deception in food law: Imitation, mitigate and beauty - Part 1. Fleischwirtschaft 92:38.

IBGE - Instituto Brasileiro de Geografia e Estatística. 2012. POF (Pesquisa de Orçamentos Familiares). Available at: <ftp://ftp.ibge. gov.br/Perfil_Municipios/2012/munic2012.pdf>. Accessed on: May $12,2012$.

Ilbery, B. and Kneafsey, M. 2000. Producer constructions of quality in regional speciality food production: a case study from South-west England. Journal of Rural Studies 16:217-30.

IMF - International Monetary Fund. 2012. Income data. Available at: $<$ http://www.imf.org/external/index.htm>. Accessed on: Feb. 10, 2012.

Inazawa, F. and Baptista, S. G. 2012. Modelo conceitual de comunicação da informação para estudos de interação informacional baseado em competências conversacionais em serviço de referência. Perspectivas em Ciência da Informação 17:169-184.

Insch, A. and Jackson, E. 2014. Consumer understanding and use of country-of-origin in food choice. British Food Journal 116:62-79.

Kopetz, C. E.; Kruglanski, A. W.; Arens, Z. G.; Etkin, J. and Johnson, H. M. 2012. The dynamics of consumer behavior: a goal systemic perspective. Journal of Consumer Psychology 22:208-223.

Kotler, P. 2006. Administração de marketing. 12ed. Pearson Prentice Hall, São Paulo.

Medeiros, J. F. and Cruz, C. M. L. 2006. Comportamento do consumidor: Fatores que influenciam no processo de decisão de compra dos consumidores. Teoria e Evidência Econômica 14(Especial ed.):167-190.
Mitchell, M.; Brunton, N. P. and Wilkinson, M. G. 2012. Sodium and ready meals: a survey of Irish consumer awareness. International Journal of Consumer Studies 36:317-326.

Moser, R. and Rafaelli, R. 2012. Consumer preferences for sustainable production methods in apple purchasing behavior: a non-hypothetical choice experiment. International Journal of Consumer Studies 36:141-148.

Notarniloca, B.; Hayashi, K.; Curran, M. A. and Huisingh, D. 2012. Progress in working towards a more sustainable agri-food industry. Journal of Cleaner Production 28:1-8.

OECD - Organization for Economic Co-operation and Development. 2012. Statistics. Available at: <http://stats.oecd.org/index. aspx?queryid=306>. Accessed on: Feb. 10, 2012.

Olsen, N. V.; Sørheim, O. and Næs, T. 2012. Likelihood of buying healthy convenience food: An at-home testing procedure for readyto-heat meals. Food Quality and Preference 24:171-178.

Pindyck, R. S. and Rubinfeld, D. L. 2004. Microeconomia. Pearson, São Paulo.

Pinho, C. P. S.; Diniz, A. S.; Arruda, I. K. G.; Lira, P. I. C.; Cabral, P. C.; Siqueira, L. A. S. and Batista Filho, M. 2012. Consumption of foods that protect against and promote cardiovascular disease by adults from Pernambuco State, Brazil. Revista de Nutrição 25:341-351

Poccard-Chapuis, R.; Ferreira, L.; Nahum, B.; Carvalho, S. and Tourrand, J. 2010. Cattle production in the Amazon Rainforest: reasons for the success, challenges for ecological intensification. Advances in Animal Biosciences 1:520-520.

Realini, C. E.; Font I Furnols, M.; Sañudo, C.; Montossi, F.; Oliver, M. A. and Guerrero, L. 2013. Spanish, French and British consumers' acceptability of Uruguayan beef, and consumers' beef choice associate with country of origin, finishing diet and meat price. Meat Science 95:14-21.

Rezende, D. C. and Avelar, A. E. S. 2012. Factors that influence the consumption of food outside the home in Brazil. International Journal of Consumer Studies 36:300-306.

Ridoutt, B. G.; Sanguansri, P.; Freer, M. and Harper, G. S. 2012. Water footprint of livestock: comparison of six geographically defined beef production systems. International Journal of Life Cycle Assessment 17:165-175.

Ruviaro, C. F.; Gianezini, M.; Brandão, F. S.; Winck, C. A. and Dewes, H. 2012. Life cycle assessment in Brazilian agriculture facing worldwide trends. Journal of Cleaner Production 28:9-24.

Shepherd, R.; Sparks, P.; Bellier, S. and Raats, M. M. 1991. The effects on information on sensory ratings and preferences: The importance of attitudes. Food Quality and Preference 3:147-155.

Soler, C. and Plaza, M. C. 2012. Integration of ethnic food into Swedish food rituals. The cultural fitness of tacos. Appetite 58:928-935.

Stilmant, D.; Jamar, D.; Hanus, H.; Stassart, P. and Seutin, Y. 2010. Working together in order to create a production system of specialquality beef so as to solve environmental problems. Fourrages 201:67-70

Taylor, A. W.; Coveney, J.; Ward, P. R.; Dal Grande, E.; Mamerow, L.; Henderson, J. and Meyer, S. 2012. The Australian food and trust survey: Demographic indicators associated with food safety and quality concerns. Food Control 25:476-483.

Tellez-Delgado, R.; Mora-Flores, J. S.; Martínez-Damián, M. A.; García-Mata, R. and García-Salazar, J. A. 2012. Characterization of the beef consumer in the metropolitan area of the Valley of Mexico. Agrociencia 46:75-86.

United Nations. 2012. Statistics. Available at: $<$ http://www.un.org/en/>. Accessed on: Feb. 10, 2012.

Vanhonacker, F.; Van Loo, E. J.; Gellynck, X. and Verbeke, W. 2013. Flemish consumer attitudes towards more sustainable food choices. Appetite 62:7-16. 
Velho, J. P.; Barcellos, J. O. J.; Lengler, L.; Elias, S. A. and Oliveira, T. E. 2009. Disposição dos consumidores porto-alegrenses à compra de carne bovina com certificação. Revista Brasileira de Zootecnia 38:399-404.

Voordouw, J.; Antonides, G.; Fox, M.; Cerecedo, I.; Zamora, J.; Caballer, B. D.; Rokicka, E.; Cornelisse-Vermaat, J.; Jewczak, M.; Starosta, P.; Kowalska, M. L.; Jedrzejczak-Czechowicz, M.; Vazquez-Cortes, S.; Escudero, C.; de Blok, B. F.; Dubois, A.; Mugford, M. and Frewer, L. J. 2012. Subjective welfare, wellbeing, and self-reported food hypersensitivity in four European countries: Implications for European policy. Social Indicators Research 107:465-482.
White, T. A.; Snow, V. O. and King, W. M. 2010. Intensification of New Zealand beef farming systems. Agricultural Systems, Amsterdam 103:21-35.

WHO - World Health Organization. 2012. Statistics. Available at: $<$ http://apps.who.int/ghodata/?vid=710>. Accessed on: Feb. 10, 2012.

World Bank. 2012. Data. Available at: $<$ http://data.worldbank.org/topic $>$. Accessed on: Feb. 10, 2012.

Worldwatch Institute. 2012. Consumer trends. Available at: $<$ http:// www.worldwatch.org/node/810>. Accessed on: Feb. 10, 2012.

Worsley, A.; Thomson L. and Wang, W. C. 2011. Australian consumers' views of fruit and vegetable policy options. Health Promotion International 26:397-407. 